\title{
Implementing Circular Economy and Its Impact on Consumer Ecological Behavior
}

\author{
Farhana Ferdousi ${ }^{1}$, Dong Qiang ${ }^{2}$ \\ ${ }^{1}$ School of Economics and management, Wuhan University, \\ Wuhan, P.R. China \& Lecturer, South East University, \\ Bangladesh \\ ${ }^{2}$ School of Economics and management, Wuhan University, \\ Wuhan, P.R. China \\ E-mail: dfferdousi@gmail.com, olivier.ma.dq@gmail.com)
}

\begin{abstract}
Aclimate changes, scarcity of water \& energy resources and global challenges, a circular economy (CE) offers huge business opportunities to have greener products with adequate response from the consumers. The pioneering companies are now leading the way on a circular economy, but to drive broader changes it is critical to collect and share data, spread best practice, invest in innovation and encourage consumers with adequate green product information. Therefore, this study attempts to investigate whether any awareness creating message either from the government, enterprises or media influences consumer behavior toward buying green products. The finding explored positive responses of the consumer toward ecological behavior and green purchase intention. This study argued that widespread implementation of circulareconomy approaches would require profound changes in industrial practice and patterns of consumption.
\end{abstract}

Key words: Circular Economy; Ecological consumer behavior; Green purchase intention 


\section{INTRODUCTION}

Circular economy (CE) is a systematic project to "reduce, reuse, recycle" the production and consumption processes in order to reduce energy consumption and waste production. Moving towards the CE will require a paradigm shift in the way things are made - putting sustainability and closed-loop thinking at the heart of business models and industrial organization. This has profound implications for society, since 'how we make things dictates not only how we work but what we buy, how we think, and the way we live'(Womack, 1990). In China, the CE is defined in legislation as a generic term for reducing, reusing and recycling activities conducted in the process of production, circulation and consumption. As the green business is now becoming a new trend, it becomes the priority to the Chinese Government. In the recent years, the Chinese Government has be $\mathrm{n}$ seriously involved in many green projects, namely in green technology, promoting green business and encouraging a green consumerism among Chinese. In accordance with the requirements of sustainable development $<$ PRC Circular Economy Promotion Law $>$ has been enacted from $1^{\text {st }}$ January, 2009. It is expected that promotion of such law will encourage the Chinese people to be more responsive to environmental issues and adopting their ecological behavior to buy green products that will stimulate the industry to adopt more green business practices and stimulate the economy to grow more sustainably. But there is very little evidence that whether such law has impacted on consumers' ecological behavior in their conventional lifestyles. Ricky Y. K. Chan, (2001) also argued that to better understand the environmental movement of a particular nation, an examination of how its consumers view and feel about ecological issues, and how they behave accordingly, serves as a good starting point. Therefore, this study will attempt to investigate the impact of implementing circular economy on the consumers' ecological behaviors and green purchase intention. Consequently, the study will analyze whether any message for being ecological or green product information enhances their intention to buy green products or their existing ecological behavior and environmental concerns are responsible for their green purchase intention.

\section{LITERATURE REVIEW AND HYPOTHESIS DEVELOPMENT}

\section{Environmental knowledge and ecological consumer behavior}

According to D"Souza, Taghian and Lamb (2006) environmental knowledge evolves in two forms; (1) consumers have to educated to be understand the impact of a product to environment; and (2) consumer knowledge in the product itself being produced in an environmentally friendly way. There are many ways on how consumers seeking for knowledge and evidences suggest that consumers are seeking knowledge by reading product label (D'Souza \& Lamb, 2006) If the consumer has knowledge about the environmental issues, then their awareness level would increase and thus would, potentially, promote favorable attitudes towards green products (Aman, Harun, \& Hussein, 2012). Our study applies similar context in designing knowledge of the consumer. Two dimensions have been used: (1) information regarding circular economy available through public announcement, government service rule, newspapers, magazines and other personal observation and (2) consumer self-knowledge about ecological product information available either on the product itself or through previous purchasing experiences. Based on the available literature following hypothesis have been developed: 
H1: Consumers those who have clear knowledge about circular economy will (a) adopt ecological consumer behavior and (b) will have more positive intention to purchase greener products.

H2: Green product related information will (a) positively influence consumers' ecological buying behavior and (b) will increase consumers' green purchase intention.

\section{Consumers' concern toward the environments}

According to R.Y.K. Chan \& Lau, (2000) both ecological concern and knowledgeare important predictors of consumers" green purchase intention. By using structural equation model, Chan and Lau (2000) demonstrated that a strong positive relationship exist between ecological concern and green purchase intention. However, Paco, Raposo, \& Filho, (2009) showed a contradictory findings, which, although their samples concern about the environment, but they did not turn their concerns into action and they rarely taking part in environmental events. Their concerns were more related to economic factors rather than environmental factors. McKinsey \& Company global survey indicated that 87 percent of consumers are concerned about the environmental impacts of the products they buy; however, only 33 percent of those same consumers indicated they are ready to or have made green product purchases (Bonini \& Oppenheim, 2008). A study in Hong Kong by Chung \& Leung, (2007) also explored that large percentage of respondents in their study, while understanding the importance of a specific environmental action and feeling a responsibility for the environmental behavior (i.e., recycling), do not consistently carry out that behavior. Researchers have shown that the "value-action gap" is a widespread phenomenon, resulting in less frequent adoption of environmental behaviors (Honabarger, 2011). Therefore, due to the mixed results from previous studies on the relationship of Environmental Concern and Green Purchase Intention, it is imperative to investigate the relationship of these two variables, thus it is hypothesized that:

H3: People those have concern for environment are generally intended to adopt (a) ecological behavior and (b) consequently will have more intentions for buying greener products.

\section{Green purchase intention and consumer ecological behavior}

Nik Abdul Rashid, (2009) defined green purchase intention as the probability and willingness of an individual to give preference to green product over conventional products in their purchase considerations. It is expected that green consumers (who adopted green or ecological behavior) will generally have strong intentions to purchase green products.

Diamantopoulos et al. summarized socio-demographic surveys made in 1966-1994 to describe the green consumer. Many of the surveys aimed at identifying typical demographic qualities of the green consumer. For example, females, young people and people with a relatively high education and income were identified as most likely to engage in green consumer behavior (Straughan \& Roberts, 1999). There are also surveys, using psychographic characteristics such as political orientation and environmental concerns to identify the green consumer. Such characteristics turned out to be better at explaining variations in green consumer behaviour than demographic criteria (Straughan \& Roberts, 1999). Perceived consumer effectiveness (i.e. the individual's belief that his or her efforts will make a difference) has been particularly pointed out as being useful in predicting actual buying behavior (JA Ottman, 2003; Peattie, 2001; Straughan 
\& Roberts, 1999). However, it is argued that green is not a fixed character of a consumer. The context in which the purchase is made is of great importance for whether or not people will chose the green alternative (Biel A, 1999; Meyer, 2001; Peattie, 2001). The same consumer may well make green purchase decisions in one situation but not in another. Green buying behavior is not determined by the characteristics of consumer alone (Rex \& Baumann, 2007). Therefore, further investigation is required whether ecological consumers are practically more willing to buy greener products.

H4: People those who have adopted ecological behavior are generally intended to buy green products.

\section{RESEARCH MODEL}

In an attempt to better understand people's performance of eco friendly acts, Maloney, Ward, \& Braucht, (1975) advocate the importance of determining these people's knowledge of the environment (ecological knowledge), how they feel about it (ecological affect), what commitment they are willing to make (verbal commitment or intention), and what commitment they do make (actual commitment) (see also Maloney et al., 1975). Researchers following this paradigm further assert that an individual's ecological behavior is highly dependent upon his/her ecological knowledge, affect, and intention (K.Chan \& E. Yam, 1995). The model constructed for this study is in line with the above mentioned literature.

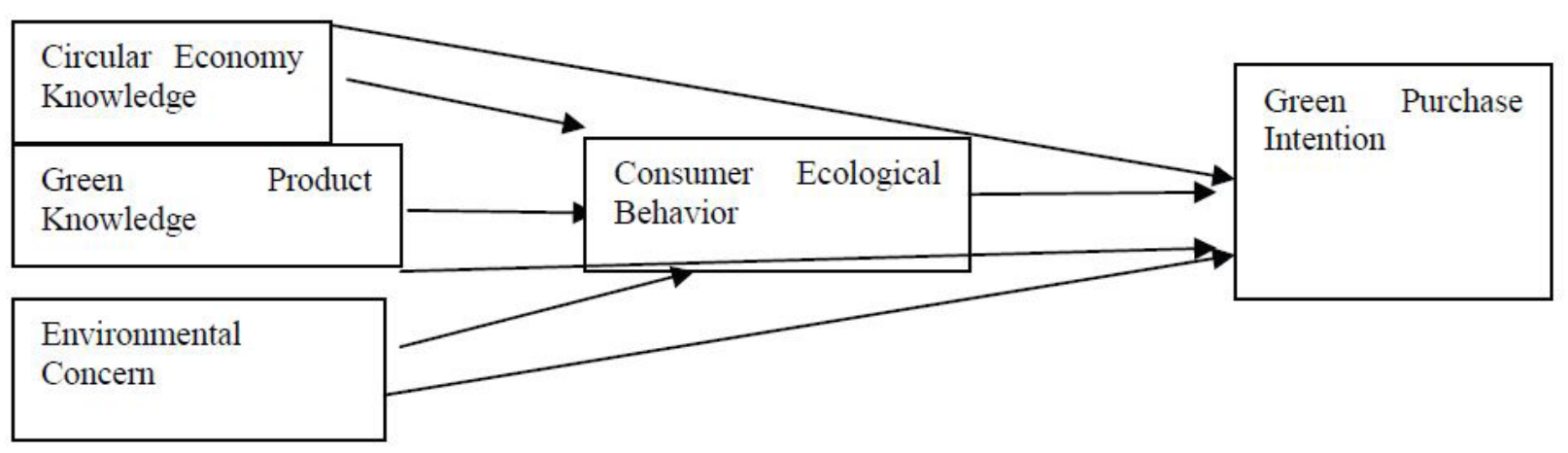

Figure 1 Model: Factors Predicting Consumer Green Purchase Intentions

\section{METHODOLOGY}

A total of 300 self-administered questionnaires were distributed evenly, by using online and offline questionnaire, among the respondents living in Wuhan, capital of Hubei Province, in China. A total of 270 questionnaires (190 online questionnaires and 80 offline questionnaires) were returned and only 175 were usable. The other questionnaires were unusable because the respondents have left a few questions unanswered.

The questionnaire consisted of four (4) sections. Section A of the questionnaire was on respondents' demographic profile such as gender, age, education and occupation. Section B of the questionnaire which contained eight (8) questions measured on the knowledge about the circular economy (3 questions) and green product related information based on a five (5) point Likert scale (5 questions). Section $\mathrm{C}$ of the questionnaire which contained five (5) questions which will be measured on the respondents green purchasing behavior based on a five (5) point Likert 
scale. Section $\mathrm{D}$ of the questionnaire measured on respondents' general environmental behavior which contain nine (9) questions based on a five (5) point Likert scale. The last section, Section E of the questionnaire ha four (4) corresponding intention statements to measure respondents' intention to purchase green products based on five (5) point Likert Scale (1= Strongly Disagree, $5=$ Strongly Agree). This section (D) is designed based on the typology of the green consumers by US Roper Starch Worldwide (Charter, Peattie, Ottman, \& Polonsky, 2002).

Descriptive statistics, correlation and regression analysis have been conducted to analyze the data. Data analyses have been conducted based on SAS 9.1.3 version.

\section{FINDINGS OF THE ANALYSIS}

\section{Descriptive statistics \& correlation analysis}

Descriptive statistics of the result shows that Chinese consumers are moderately aware about the green products information which is usually circulated by the company either through their product labeling or green promotional activities. Consumers also have positive and moderate intention to purchase green products. But their knowledge about the circular economy, environmental concern and ecological behavior yet needs to be lifted up. Correlations of the variables are highly significant with the green purchase intention of the consumers. Tables showing descriptive statistics and correlation analysis are not given here due to page limitation.

\section{Regression analysis}

Two regression models $(1 \& 2)$ have been run for this study. Model-1 shows the impact of awareness about circular economy, green product related information which is available on the product itself and consumers' environmental concern on the consumers' ecological behavior. Results show that green product information/knowledge and environmental concern of the consumer has highly significant ( $1 \%$ level) relationship with their ecological behavior which suggest that consumers those who have good concerns about environments will respond to more ecological consumer behavior. Similarly, if company's take more initiatives to promote greener products consumer will be motivated to buy their products. And consumers' ecological buying behavior ultimately increases their intention to buy green product which is also exhibited in model-2 (ecological consumers will show $48 \%$ more willingness to buy green products rather than the general consumers). Therefore, based on model -1 and Model -2 we can accept hypothesis $(2,3 \& 4)$, as the variables; green product knowledge, environmental concern and ecological consumer behavior, have highly significant (with P-value $.000, .002, \& .000$ respectively) relationship with green purchase intention. Only one variable indicating circular economy related information does not have any significant relationship with both ecological consumer behavior and green purchase intention. This result has similarity with the views of previous researchers those who have supported "value-action-gap" in explaining consumer green purchasing behavior. Therefore, it is evident that the Chinese Government's "Circular Economy Promotion Law" yet has not been as much effective as it was expected to change its citizen's ecological behavior. 
Table 1 Regression Model

\begin{tabular}{|c|c|c|c|c|c|c|}
\hline \\
\hline & \multicolumn{3}{|c|}{ Model 1} & \multicolumn{3}{|c|}{ Model 2} \\
\hline \multirow{2}{*}{$\begin{array}{c}\text { Dependent } \\
\text { variable }\end{array}$} & \multicolumn{3}{|c|}{ Consumer ecological behavior } & \multicolumn{3}{|c|}{ Green Purchase Intention } \\
\hline & $\begin{array}{l}\text { Unstandardized } \\
\text { coefficient (stan- } \\
\text { dard error) }\end{array}$ & t-value & Sig & $\begin{array}{l}\text { Unstandardized } \\
\text { coefficient (stan- } \\
\text { dard error) }\end{array}$ & t-value & Sig \\
\hline Constant & $0.932(.312)$ & t-value & 0.003 & $0.416(.358))$ & 1.164 & 0.246 \\
\hline $\begin{array}{l}\text { Circular eco- } \\
\text { nomy know- } \\
\text { ledge }\end{array}$ & $0.026(.073)$ & 2.985 & 0.724 & $-0.084(.081)$ & -1.032 & 0.303 \\
\hline $\begin{array}{l}\text { Green Product } \\
\text { knowledge }\end{array}$ & $0.291(.075)$ & 0.353 & 0.000 & $0.368(.087)$ & 4.215 & 0.000 \\
\hline $\begin{array}{c}\text { Environmental } \\
\text { concern }\end{array}$ & $0.295(.094)$ & 3.878 & 0.002 & $0.339(.108)$ & 3.148 & 3.148 \\
\hline \multirow{3}{*}{$\begin{array}{l}\text { Consumer eco- } \\
\text { logical behavior }\end{array}$} & & 3.146 & & $0.477(.085)$ & 5.594 & 0.000 \\
\hline & R-squared & $\begin{array}{l}\text { Adjusted } \\
\text { R-squared }\end{array}$ & $\begin{array}{l}\text { ANOVA/F } \\
\text { value (Sig) }\end{array}$ & R-squared & $\begin{array}{l}\text { Adjusted } \\
\text { R-squared }\end{array}$ & $\begin{array}{l}\text { ANOVA (F } \\
\text { value) }\end{array}$ \\
\hline & 0.210 & 0.196 & $\begin{array}{l}15.144 \\
(0.000)\end{array}$ & 0.442 & 0.429 & $\begin{array}{l}33.641 \\
(0.000)\end{array}$ \\
\hline
\end{tabular}

\section{CONCLUSION}

To advance a country's green revolution, McGougall, (1993) asserts that the role of consumers is essential. This assumption is supported by the evidence that $30-40 \%$ of environmental degradation has been brought about by the consumption activities of private households. More importantly, if consumers exhibit a high degree of ecological consciousness and channel it to corresponding eco-friendly or green purchases, it is likely that profit-driven enterprises will be strongly motivated to adopt the concept of green marketing in their operations (Ricky Y. K. Chan, 2001). The dynamics of this buyer-seller interaction will consequently lead to further advancement of the green revolution across the whole country (J Ottman, 1992). Our study investigated only whether Chinse consumers are having incremental intention to adopt ecological behavior and purchase greener products as the country's government are initiating several policies to control environmental degradation. And findings of our study suggest that Chinese government initiative to shape circular economy is yet in infant stage to change its citizens' ecological behavior.

\section{FUTURE RESEARCH}

Our study only concentrated on investigating impact of circular economy on ecological consumer behavior and green purchase intentions, but the circular economy focuses more on reducing environmental degradation through redirecting its resource flow, where consumer ecological behavior plays a partial role, as there are some other key player; i.e., manufacturer, seller, other economic agents etc. to build circular economy. Therefore, further research is needed to show overall impact of circular economy in other areas according to its objectives. 


\section{BIBLIOGRAPHIC REFERENCES}

[1] Aman, A. H. L., Harun, A., \& Hussein, Z. The Influence of Environmental Knowledge and Concern on Green Purchase Intention the Role of Attitude as a Mediating Variable[J]. British Journal of Arts and Social Sciences, 2012, 7(2):581-583

[2] Biel A, L. M., Ga“rling T. Ko"pbeteendets psykologi: Miljo"medvetenhet och vanor [The psychology of buying behaviour: environmental consciousness and habits]. . In: Ekstro"m KM, Forsberg H, editors. Den flerdimensionella konsumenten [the multi-dimensional consumer][J]. Go"teborg:Tre Bo"cker,1999, 129-146

[3] Bonini, S., \& Oppenheim, J. Cultivating the Green Consumer[J]. Stanford Social Innovation Review., 2008, 6(4): 56 - 61

[4] Chan, R. Y. K. Determinants of Chinese Consumers' Green Purchase Behavior[J]. Psychology \&Marketing,2001, 18(4): 389-413

[5] Chan, R. Y. K., \& Lau, L. B. Y. Chan, R.Y.K., and Lau, L. B.Y. Antecedents of Green Purchases: A survey in China[J]. Journal of Consumer Marketing, 2000, 17(4): 338-357

[6] Charter, M., Peattie, K., Ottman, J., \& Polonsky, M. Marketing and sustainability. Association with The Centre for Sustainability Design[J]. UK: Centre for Business Relationships, Accountability, Sustainability and Society (BRASS), 2002

[7] Chung, S., \& Leung, M. M. The Value-Action Gap in Waste Recycling: The Case of Undergraduates in Hong Kong[J]. Environmental Management, 2007, 40: 603 - 612

[8] D'Souza, C., Taghian, M., \& Lamb, P. An Empirical Study On The Influence Of Environmental Labels On Consumers[J]. Corporate Communications: An International Journal, 2006, 11(2): 162173

[9] Honabarger, D. Bridging the Gap: The Connection Between Environmental Awareness, Past Environmental Behavior, and Green Purchasing[J], 2011.

[10] K.Chan, R. Y., \& E. Yam. Green movement in a newly industrializing area: A survey on the attitudes and behavior of the Hong Kong citizens[J]. Journal of Community and Applied Social Psychology, 1995 5: 273-284

[11] Maloney, M. P., Ward, M. P., \& Braucht, G. N. Psychology in action: A revised scale for the measurement of ecological attitudes and knowledge[J]. American Psychologist, 1975, 787- 790

[12] McGougall, G. H. G. The green movement in Canada: Implications for marketing strategy[J]. Journal of International Consumer Marketing, 1993, 5: $69-87$

[13]Meyer, A. What's in it for the customers? Successfully marketing green clothes[J]. Business Strategy and the Environment, 2001, 10: 310-317 
[14] Nik Abdul Rashid, N. Awareness Of Eco-label In Malaysia's Green Marketing Initiative[J]. International Journal of Business and Management, 2009, 4(8): 132-141

[15] Ottman, J. Sometimes consumer will pay more to go green[J]. Marketing News,1992, 16

[16] Ottman, J. Empowering the people In Business[J], 2003, 25(6): 32

[17] Paco, A. F., Raposo, M. L., \& Filho, W. L. Identifying The Green Consumer: A Segmentation Study[J]. Journal of Targeting, Measurement and Analysis for Marketing, 2009, 17(1): 17-25

[18] Peattie, K. Golden goose or wild goose? The hunt for the green consumer[J]. Business Strategy and the Environment, 2001, 10: 187-199

[19] Rex, E., \& Baumann, H. Beyond ecolabels: what green marketing can learn from conventional marketing[J]. Journal of Cleaner Production, 2007, 15: 567-576

[20] Straughan, R., \& Roberts, J. Environmental segmentation alternatives: a look at green consumer behaviour in the new millennium[J]. Journal of Consumer Marketing, 1999. 16(6): 558-575

[21] Womack, J., Jones, D. and Roos, D. The Machine That Changed the World[J]. (Sydney: Simon and Schuster), 1990, 5: 9 